\title{
Alpine Tectonic-magmatic-metallogenic Peculiarities in West Baluchestan, Middle East: New Data, "Hot" Tectonics, Inclusions, Discussion, Hydrocarbons (HC), and Constraints
}

\author{
A. Romanko ${ }^{1, *}$, N.A. Imaverdiyev ${ }^{2}$, V. Prokofiev ${ }^{3}$, I. Vikentiev ${ }^{3}$, A. Savichev ${ }^{1}$, S. Stepanov ${ }^{1}$ \\ ${ }^{1}$ Geological Institute, Academy of Sciences (RAS), Moscow, Russian Federation \\ ${ }^{2}$ State University of Baku, Baku, Republic of Azerbaijan \\ ${ }^{3}$ Institute of geology of ore deposits, Academy of Sciences (RAS), Moscow, Russian Federation \\ *Corresponding Author: a-romanko@ya.ru
}

Copyright (C) 2013 Horizon Research Publishing All rights reserved.

\begin{abstract}
A satisfactory tectonic-magmatic-metallogenic correlation in the East Iran, Middle East for Alpine time was revealed in the region (mainly metallogeny - led by outstanding regional trio: Drs. E. Romanko, A. Houshmand-Zadeh, and M.A.A. Nogol Sadat). Geological northeastern zonation and "hot" tectonics due to the African superplume activity including probably slab delamination is revealed too. Strongly dominated rocks of calc-alkaline and shoshonite series deal with a known subduction of Arabian plate beneath the Central Iran block. Intraplate African superplume-related rocks are subalkaline - alkaline ones including Quaternary carbonatites in Hanneshin, Afghanistan. Tectonic-magmatic pair could be postulated here. General oil / hydrocarbons (HC) productivity decreasing to the north could be in an agreement with corresponding decreasing of African superplume activity too. Regional economic $\mathrm{Cu}-\mathrm{Au}$ etc. metallogeny is mainly stipulated by a subduction mentioned.
\end{abstract}

Keywords East Mediterranean Belt, West Baluchestan, Middle East, Magmatism, Tectonics, Rock Chemistry, Mineralogy, Metallogenic Peculiarities, Melt and Fluid Inclusions, Northeastern Tectonic-Magmatic-Metallogenic and Oil - Hydrocarbons (HC) Zoning

\section{Introduction}

Middle East is geologically, economically... exclusively interesting region, however, very irregular studied. Great importance of its regional study is obvious. Metallogeny and geology of poorly studied East Iran close a very impressive Alpine - Himalayan structures junction (Khain, 2001; Khain, Leonov 1988; E. Romanko et al, 1984; Houshandzadeh et al.,
1986; Imamverdiyev, 2000; Stocklin et al., 1965; Milanovsky, Koronovsky, 1973; Abdullah et al, 1980; etc., Fig. 1) recently studied under the leadership of outstanding trio - known regional specialists Drs. E. Romanko, A. Houshmandzadeh, and M. A. A. Nogol Sadat.

\section{Methodology}

Methodology of our research includes traditional general geological investigations including field works etc., then also special ones, and joint analysis of all materials available since known works led by Dr E. Romanko (E. Romanko, 1984) etc.

\section{Results}

We present new data on magmatic rocks of the region studied: dominated Paleocene - Quaternary subduction-related calc-alkaline rocks and, rare, Eocene Oligocene shoshonitic-latitic rocks (first group) and principally other subordinate rocks younger Neogene Quaternary intraplate subalkaline and rarely - alkaline ones (second group).

Rocks of the first group (subduction-related differentiated calc-alkaline rocks: basalts - dominated andesites - rhyolites, granodiorites, etc.) are the products of a large subduction of the Tethys lithosphere and Arabian plate beneath the Central Iran block or microplate (Fig. 1).

This process is confirmed by the regional tectonic analysis, tomography by known J. Ritsema's team (Bull et al., 2009 etc.) and petrology and geochemistry (Imamverdiyev, 2000; Romanko et al., 2012; etc., Figure 1). Catastrophic earthquakes of ca. $8 \mathrm{M}$ and more on the Richter scale, unfortunately, are not rare here. A recent catastrophic 
example is the 2003 Bam earthquake.

Formation of the antipodes - intraplate K-Na subalkaline and alkaline rocks subordinate (including real carbonatites of Afghanistan and Arabia). The second group rocks relate to the African superplume activity with the "hot" tectonics here as (as seen from Table 1 for "hot" intraplate rocks (similar for Neogene lamproites of Algeria etc. - E. Romanko et al., 1988; Romanko et al., 2012; etc.). They are trachybasalts, basic trachyandesites, and trachyandesites on classification and discriminated digrams (Bogatikov et al., 1987; Luchitsky, 1985, Yarmolyuk et al., 2001 etc.) and seen from
Tables 1 and 6 . Data in Table 5 are in satisfactory agreement on rock-minerals relation. No data about serious post-magmatic processes exist. Ca-rich minerals are in a good agreement with carbonatites of Hanneshin, Afghanistan, and carbonatites-related rocks.

These rocks, in contrast to the calc-alkaline, characterized by an enrichment of both LILIE - K, Rb, Ba etc. and HFSE $\mathrm{Nb}, \mathrm{Y}, \mathrm{Ta}, \mathrm{Zr}, \mathrm{Ti}, \mathrm{P}$ etc. with a characteristic high $\mathrm{Eu} / \mathrm{Eu}^{*}$ more than 1.1 as seen from Tables 1 and 7 . Increased concentration of $\mathrm{P}_{2} \mathrm{O}_{5}$ - sometimes more than $1.0 \%$ - is a characteristic feature of the second group of rocks.

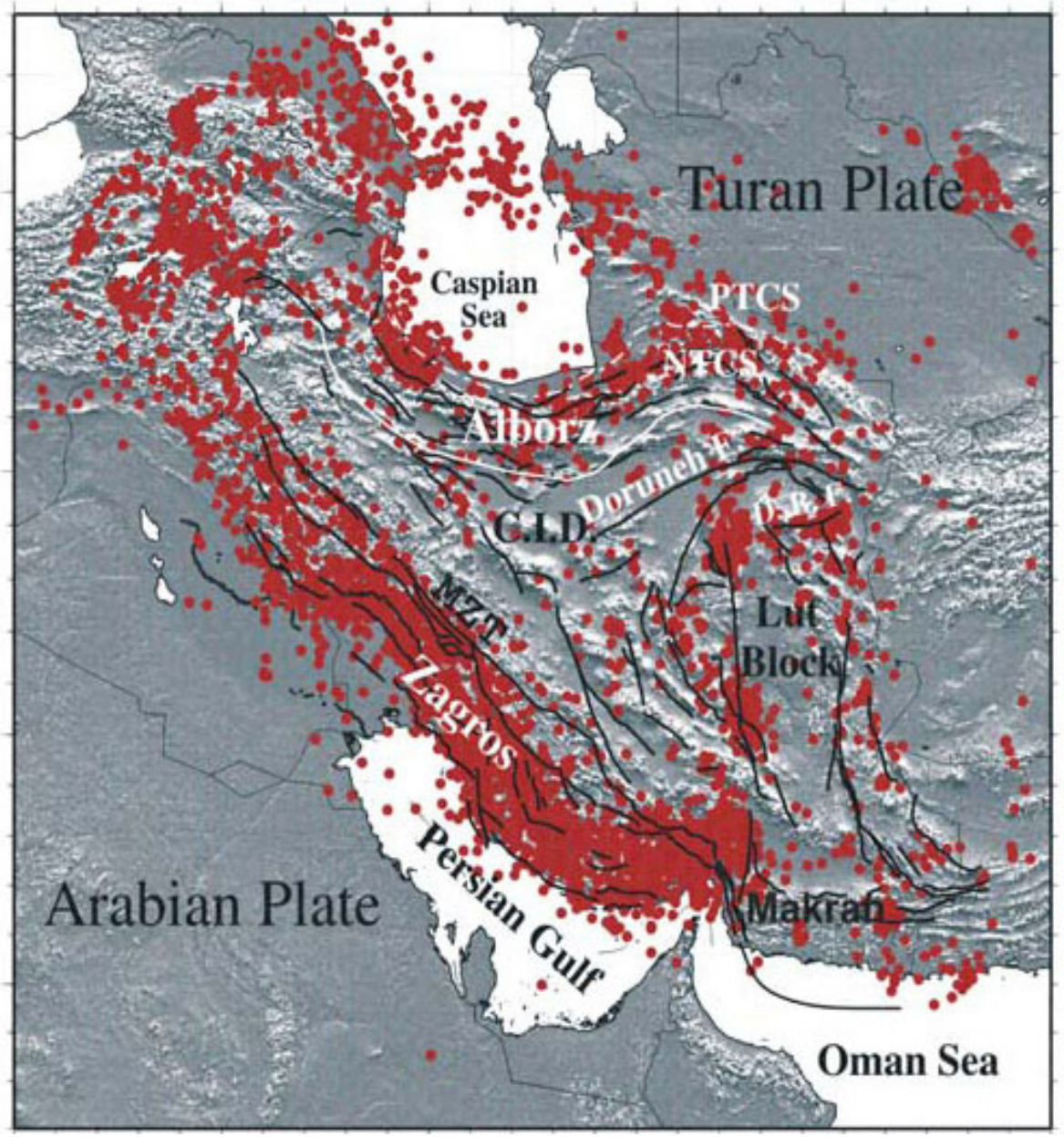

Figure 1. Distribution of earthquake epicenters in the Middle East due to detailed work (Alinaghi et al., 2007). We can see known Lut Block and immediately next to the east studied East Iran mobile zone area (Khain, 2001, Hushmandzadeh et al., 1987, E. Romanko et al., 1984, etc. . 
Alpine Tectonic-magmatic-metallogenic Peculiarities in West Baluchestan, Middle East:

New Data, "Hot” Tectonics, Inclusions, Discussion, Hydrocarbons (HC), and Constraints

Table 1. Major and trace elements composition in the rocks.

\begin{tabular}{|c|c|c|c|c|c|c|c|c|c|}
\hline $\begin{array}{c}\mathrm{N} \\
\text { Compo-nent }\end{array}$ & 1 & 2 & 3 & 4 & 5 & 6 & 7 & 8 & 9 \\
\hline $\mathrm{SiO}_{2}$ & 48.17 & 57.80 & 54.50 & 54.00 & 60.69 & 65.39 & 65.10 & 85.00 & 58.67 \\
\hline $\mathrm{TiO} 2$ & 2.20 & 1.31 & 1.87 & 1.52 & 0.36 & 0.42 & 0.51 & 0.60 & 1.70 \\
\hline $\mathrm{Al}_{2} \mathrm{O}_{3}$ & 13.80 & 17.48 & 15.94 & - & 15.32 & 13.71 & 15.54 & 4.00 & 15.13 \\
\hline $\mathrm{Fe}_{2} \mathrm{O}_{3}$ & 9.32 & 4.37 & 6.39 & 6.25 & 2.70 & 3.25 & 2.42 & 3.21 & 6.69 \\
\hline $\mathrm{FeO}$ & 2.56 & 1.07 & 0.40 & - & 2.07 & - & 2.32 & 1.10 & 2.19 \\
\hline $\mathrm{MnO}$ & 0.14 & 0.09 & 0.09 & 0.08 & 0.09 & 0.057 & 0.13 & 0.02 & 0.09 \\
\hline $\mathrm{MgO}$ & 5.75 & 2.27 & 3.37 & - & 3.65 & 1.39 & 1.72 & 0.52 & 2.28 \\
\hline $\mathrm{CaO}$ & 8.98 & 7.10 & 7.58 & 7.40 & 3.90 & 2.08 & 2.80 & 0.29 & 1.77 \\
\hline $\mathrm{Na}_{2} \mathrm{O}$ & 4.93 & 5.11 & 5.81 & - & 3.64 & 2.87 & 3.36 & 0.28 & 5.06 \\
\hline $\mathrm{K}_{2} \mathrm{O}$ & 1.31 & 1.42 & 1.73 & 1.09 & 4.38 & 4.51 & 4.59 & 0.21 & 2.05 \\
\hline $\mathrm{P}_{2} \mathrm{O}_{5}$ & 0.23 & 0.61 & 1.05 & - & 0.31 & 0.11 & 0.20 & 0.09 & 0.30 \\
\hline $\mathrm{Rb}$ & 30 & 19 & 20 & 15 & 145 & 117 & 109 & 7 & 47 \\
\hline $\mathrm{Ba}$ & 375 & 293 & - & 292 & 1230 & 577 & 1597 & 390 & 557 \\
\hline $\mathrm{Sr}$ & 1185 & 912 & 4470 & 950 & 870 & 232 & 359 & 440 & 263 \\
\hline $\mathrm{Ni}$ & 86 & 53 & 58 & 59 & 50 & 7 & 13 & 10 & 44 \\
\hline $\mathrm{Co}$ & 33 & 14 & - & - & 12 & 5 & 6 & 4 & 21 \\
\hline $\mathrm{Cr}$ & 64 & 60 & 38 & /_64 & 50 & 16 & 18 & 11 & 72 \\
\hline $\mathrm{V}$ & 220 & 95 & - & - & 81 & 63 & 54 & 55 & 107 \\
\hline $\mathrm{Cu}$ & 63 & 65 & 64 & 77 & 69 & 15 & 11 & 17 & 33 \\
\hline $\mathrm{Zn}$ & 113 & 88 & 113 & 98 & 32 & 40 & 57 & 8 & 82 \\
\hline $\mathrm{Pb}$ & 5 & 20 & 51 & 5 & 20 & 27 & 22 & 20 & 10 \\
\hline $\mathrm{Zr}$ & 283 & 232 & 339 & 217 & 96 & 158 & 246 & 136 & 219 \\
\hline $\mathrm{Y}$ & 25 & 19.5 & 25 & 15 & 15 & 11 & 29 & 13 & 23 \\
\hline $\mathrm{Nb}$ & 23 & 17 & 19 & - & 5.8 & 8 & 12 & 6 & 30 \\
\hline $\mathrm{Sc}$ & 19 & 10.7 & - & 26.2 & 10 & - & - & 6.5 & 10 \\
\hline Th & 3 & 3.65 & - & 4.84 & 12 & - & 16.7 & 1 & 12 \\
\hline $\mathrm{U}$ & 1.2 & 0.99 & - & 1.31 & 1 & - & 4.62 & 3 & 3 \\
\hline $\mathrm{La}$ & 44 & 32.4 & - & 30 & 18 & - & 34.0 & 15 & 35.2 \\
\hline $\mathrm{Ce}$ & 101 & 68.3 & - & 63 & 32 & - & 64.5 & 28 & 64.2 \\
\hline $\mathrm{Nd}$ & - & 31.4 & - & - & - & - & 27 & - & 25.0 \\
\hline $\mathrm{Sm}$ & - & 6.00 & - & - & - & - & 5.6 & - & 5.1 \\
\hline $\mathrm{Eu}$ & - & 2.11 & - & - & - & - & 1.3 & - & 1.9 \\
\hline $\mathrm{Gd}$ & - & 5.08 & - & - & - & - & 4.1 & - & 4.8 \\
\hline $\mathrm{Tb}$ & - & 0.78 & - & - & - & - & - & - & 0.9 \\
\hline Er & - & 1.64 & - & - & - & - & 1.9 & - & 1.6 \\
\hline $\mathrm{Yb}$ & - & 1.26 & - & - & - & - & 1.7 & - & 1.6 \\
\hline $\mathrm{K} / \mathrm{Rb}$ & 560 & 620 & 586 & 581 & 245 & 307 & 350 & 230 & 350 \\
\hline
\end{tabular}

1 and 2 - trachybasalt (sample R71-4) and trachyandesite (sample R70-2) correspondently, Haji lake, maybe Neogene, Afghan block, 3 - trachyandesite, Baluchestan, Iran (Camp, Griffis, 1982), 4 - trachyandesite, R75wp, Lut block, 5 - syenite, Lar intrusiion with Cu-Au mineralization, maybe Miocene, 6 K-dacite, R75, Lut block, and 7 - trahydacite, standard, Kurama Ridge, Middle Tien Shan, Karamazar, Tajikistan, Late Carboniferous - Early Permian, using data and extrapolation from (Rusinov, Kovalenker, 1991; Razdolina, Moralev et al., 1993; Romanko et al., 1990; Mamajanov, 2005) 8 - leucorhyolite, R82, east Bazman stratovolcano, maybe Quarternary despite N-Q age for all this stratovolcano, 9 - trachyandesite, continental rift, standard, Proterozoic, Pechenga (Petsamo) zone, Fennoscandian or Baltic shield, Romanko et al., 1989. 
Table 2. Composition of melt inclusions glass (wt \%) in plagioclase (1, 3), host mineral $(2,4)$, host acid K-volcanite (5), leucorhyolite from Bazman stratovolcano, and plagioclase standards (7-9) due to A. Betekhtin, 1953.

\begin{tabular}{|c|c|c|c|c|c|c|c|c|c|c|c|c|c|}
\hline $\mathrm{N}$ & $\mathrm{SiO}_{2}$ & $\mathrm{TiO}_{2}$ & $\mathrm{Al}_{2} \mathrm{O}_{3}$ & $\mathrm{FeO}$ & $\mathrm{MnO}$ & $\mathrm{MgO}$ & $\mathrm{CaO}$ & $\mathrm{Na}_{2} \mathrm{O}$ & $\mathrm{K}_{2} \mathrm{O}$ & $\mathrm{P}_{2} \mathrm{O}_{5}$ & $\mathrm{Cl}$ & $\mathrm{S}$ & $\mathrm{CyMMa}$ \\
\hline 1. & 74.77 & 0.19 & 12.94 & 0.58 & 0.08 & 0.12 & 1.52 & 3.88 & 3.93 & 0.26 & 0.00 & 0.01 & 98.28 \\
\hline 2. & 58.69 & 0.01 & 24.77 & 0.23 & 0.00 & 0.01 & 6.68 & 7.22 & 0.49 & 0.00 & 0.00 & 0.01 & 98.11 \\
\hline 3. & 74.48 & 0.15 & 14.53 & 0.53 & 0.04 & 0.10 & 1.69 & 3.02 & 4.10 & 0.00 & 0.01 & 0.01 & 98.66 \\
4. & 58.36 & 0.00 & 24.71 & 0.28 & 0.02 & 0.05 & 7.15 & 6.90 & 0.46 & 0.04 & 0.00 & 0.01 & 97.98 \\
5. & 65.39 & 0.42 & 13.71 & 2.93 & 0.057 & 1.39 & 2.08 & 2.87 & 4.51 & 0.11 & - & - & - \\
\hline 6. & 77.50 & 0.60 & 13.00 & 3.98 & 0.02 & 0.52 & 0.29 & 0.28 & 0.21 & 0.09 & - & & - \\
\hline 7. & 58.16 & - & 26.57 & - & - & - & 8.35 & 6.92 & - & - & - & & - \\
\hline 8. & 56.05 & - & 28.01 & - & - & - & 10.05 & 5.89 & - & - & - & & \\
\hline 9. & 62.43 & - & 23.70 & - & - & - & 5.03 & 8.84 & - & - & - & & \\
\hline
\end{tabular}

1, 3 - melt inclusions glasses in plagioclase, 2, 4 - host minerals, 5 - host K-volcanite, 6 - leucorhyolite from stratovolcano Bazman, maybe Quaternary, 7-9 plagioclase standards: 7 - andesine, $\mathrm{SiO}_{2}=58.16$, empirical formula $-\mathrm{Na} 0.6 \mathrm{Ca} 0.4 \mathrm{All} .4 \mathrm{Si} 2.6 \mathrm{O} 8$, chemical formula andesine $-(\mathrm{Na}, \mathrm{Ca})(\mathrm{Si}, \mathrm{Al}) 4 \mathrm{O} 8$, Webmineral.com, 8 - 9 - plagioclase theoretical composition: Pl 50 (8) and Pl 25 (9), by A. Betekhtin, Moscow, 1953.

Table 3. Sum of gases by thermobarogeochemistry (cub. cm / kg)

\begin{tabular}{|c|c|c|c|}
\hline $\mathrm{N}$ & Sample & Sum of gases Cubic $\mathrm{cm} / \mathrm{kg}$ & Rock, age, notes \\
\hline 1. & R26 & 0.933 & subvolcanites and shallow intrusions, West Taftan volcano, diorites, probably Miocene \\
\hline 2. & R38 & 1.022 & Lar intrusion, Oligocene-Miocene \\
\hline 3. & R61 & 0.401 & ophiolites, Creataceous \\
\hline 4. & R85 & 0.655 & ophiolites, Cretaceous \\
\hline 5. & R35 & 12.942 & $\begin{array}{l}\text { Subvolcanites intruding CARBONATIC rocks, West Taftan volcano, maximal contain, } \\
\text { probably Oligocene-Miocene }\end{array}$ \\
\hline 6. & R66 & 1.262 & youngest $\mathrm{Cu}-\mathrm{Zn}-\mathrm{Pb}$ mineralization with $\mathrm{Au}$ and $\mathrm{Ag}$, probably Quaternary \\
\hline
\end{tabular}

Sum of gases includes $\mathrm{H}_{2}, \mathrm{O}_{2}, \mathrm{~N}_{2}, \mathrm{CO}_{2}, \mathrm{CH}_{4}, \mathrm{C}_{2} \mathrm{H}_{6}, \mathrm{C}_{3} \mathrm{H}_{8}, \mathrm{C}_{4} \mathrm{H}_{10}, \mathrm{C}_{5} \mathrm{H}_{12}$, and $\mathrm{C}_{6} \mathrm{H}_{14}$. Temperature of Au mineralization is 220 - 278oC, Oligocene-Quaternary, important Lar intrusive massif with Au up to $25.4 \mathrm{ppm}, \mathrm{T}=220-2260 \mathrm{C}$ by analyst R. Mudrogova, VNIIYG GB or Nuclear geophysics Institute, Moscow region (E. Romanko et al, 2000). Maximum of gases are in subvolcanites intruding CARBONATIC rocks. Minimum of gases are in ophiolite mélange rocks.

Table 4. ${ }^{87} \mathrm{Sr} /{ }^{86} \mathrm{Sr}(\mathrm{ISr})$ isotopic data from the rocks

\begin{tabular}{|c|c|c|}
\hline $\mathrm{N}$ & ${ }^{87} \mathrm{Sr}{ }^{8}{ }^{86} \mathrm{Sr}$ & Rock, mineral, age, notes \\
\hline 1. & $0,7039+-0,0002$ & trachyandesite, sample R70-2, Hilmand (Afghan) block, maybe Neogene \\
\hline 2. & $0,70489+-0,00018$ & trachybasalt, R71-4, lake Haji area, Hilmand (Afghan) block, maybe Neogene \\
\hline 3. & $0,70456+-0,00005$ & calk-alkaline basic andesite, R25-1, East Bazman volcano, Neogene-Quaternary \\
\hline 4. & 0,7049 & volcanite by Camp and Griffis, 1982, No data about age \\
\hline 5. & $0,7047+-0,0003$ & biotite from trachybasalt, sample 64, Shurab - Galecha, Eocene \\
\hline 6. & $0,7048+-0,0003$ & andesite, sample 206, Eocene \\
\hline 7. & 0,7051 & biotite from andesite, sample 203, Cheh-meh-Huri, Eocene \\
\hline 8. & 0,7055 & andesite, sample 193-A, no age \\
\hline 9. & 0,7059 & Late Cenozoic magma, ENd= +4.1+-0.2, Great Caucasus \\
\hline 10. & $0,7041+-0.0001$ & Late Cenozoic magma, ENd=+3, Great Caucasus \\
\hline 11. & $20.0,7040$ & \\
\hline
\end{tabular}

1-3 - author's data, 4 - after (Camp, Griffis, 1982), 5-9 - Lut block, to the west from East Iranian (mobile) zone, after Sandwall E., Turkell N. Zor E. et al., 2003, 10-11 - courtesy of Chernyshev, Bubnov, Lebedev et al., IGEM RAS, Moscow. 
Table 5. Composition of rock-forming and accessory minerals

\begin{tabular}{|c|c|c|c|c|c|c|c|c|c|c|c|c|c|}
\hline $\begin{array}{c}\text { Compo } \\
\text {-nent }\end{array}$ & 1 & 2 & 3 & 4 & 5 & 6 & 7 & 8 & 9 & 10 & 11 & 12 & 13 \\
\hline $\mathrm{SiO}_{2}$ & 55.45 & 54.11 & 55.20 & 43.79 & 44.65 & 46.25 & 46.87 & 53.86 & 54.54 & 64.49 & 68.94 & 68.61 & 0.018 \\
\hline $\mathrm{TiO}_{2}$ & 0.26 & 0.19 & 0.22 & 1.88 & 1.71 & 1.84 & 1.36 & - & - & 0.26 & - & 0.13 & 29.79 \\
\hline $\mathrm{Al}_{2} \mathrm{O}_{3}$ & 1.51 & 1.52 & 1.50 & 11.37 & 7.88 & 7.69 & 6.40 & 29.51 & 28.22 & 17.82 & 17.20 & 17.85 & 0.02 \\
\hline $\mathrm{Fe}_{2} \mathrm{O}_{3}$ & - & - & - & - & - & - & - & - & - & - & - & - & - \\
\hline $\mathrm{FeO}$ & 11.66 & 15.73 & 12.7 & 13.68 & 13.05 & 13.39 & 15.00 & - & - & 2.79 & 1.12 & 0.96 & 62.11 \\
\hline $\mathrm{MnO}$ & 0.24 & 0.34 & 0.28 & 0.28 & 0.27 & 0.24 & 0.03 & - & - & 0.16 & - & - & 0.17 \\
\hline $\mathrm{MgO}$ & 28.21 & 27.01 & 28.14 & 15.16 & 14.23 & 15.32 & 13.68 & - & - & 0.85 & 0.15 & 0.15 & 1.60 \\
\hline $\mathrm{CaO}$ & 1.89 & 1.16 & 1.93 & 10.55 & 10.48 & 10.42 & 11.51 & 8.97 & 9.99 & 1.87 & 0.47 & 0.70 & 0.08 \\
\hline $\mathrm{Na}_{2} \mathrm{O}$ & 0.32 & - & - & 2.08 & 1.31 & 1.48 & 1.40 & 5.55 & 5.59 & 9.90 & 7.09 & 7.55 & - \\
\hline $\mathrm{K}_{2} \mathrm{O}$ & - & - & - & 0.49 & 0.38 & 0.44 & 0.75 & 0.28 & 0.34 & 1.78 & 4.96 & 3.71 & - \\
\hline $\mathrm{P}_{2} \mathrm{O}_{5}$ & 0.18 & - & - & - & - & - & - & - & - & - & 0.22 & 0.22 & - \\
\hline
\end{tabular}

1-3 - Orthopyroxenes, 2-3 - standard bronzites, orthopyroxenes, 2 - from andesite and 3 - from Hb-norite, by H. Kuno, 1964; 4-7 - amphiboles; 8-9 - plagioclases; 10-12 - alkali feldspars; 13 - magnetite.

Table 6. Major elements composition in the rocks

\begin{tabular}{|c|c|c|c|c|c|c|c|c|c|c|c|c|c|}
\hline $\begin{array}{c}\mathrm{N} \\
\text { Compo-n } \\
\text { ent } \\
\end{array}$ & 1 & 2 & 3 & 4 & 5 & 6 & 7 & 8 & 9 & 10 & 11 & 12 & 13 \\
\hline $\mathrm{SiO}_{2}$ & 48.17 & 49.0 & 52.76 & 54.50 & 56.95 & 57.80 & 35.10 & 44.26 & 46.10 & 56.7 & 60.69 & 61.79 & 76.01 \\
\hline $\mathrm{TiO}_{2}$ & 2.20 & 1.69 & 1.11 & 1.87 & 1.27 & 1.31 & 0.74 & 0.81 & 0.49 & 0.60 & 0.36 & 0.52 & 0.60 \\
\hline $\mathrm{Al}_{2} \mathrm{O}_{3}$ & 13.80 & 14.1 & 17.44 & 15.94 & 16.40 & 17.48 & 13.48 & 12.70 & 10.30 & 11.1 & 15.32 & 17.10 & 12.50 \\
\hline $\mathrm{Fe}_{2} \mathrm{O}_{3}$ & 9.32 & 9.10 & 3.14 & 6.39 & 5.28 & 4.37 & 7.53 & 4.81 & 5.10 & 4.90 & 2.70 & 1.16 & 2.51 \\
\hline $\mathrm{FeO}$ & 2.56 & - & 5.40 & 0.40 & 0.46 & 1.07 & 0.73 & 0.87 & - & - & 2.07 & 3.53 & 1.21 \\
\hline $\mathrm{MnO}$ & 0.14 & 0.11 & 0.13 & 0.09 & 0.08 & 0.09 & 0.16 & 0.12 & 0.08 & 0.10 & 0.09 & 0.10 & 0.02 \\
\hline $\mathrm{MgO}$ & 5.73 & 9.23 & 5.55 & 3.37 & 3.35 & 2.27 & 5.46 & 6.60 & 9.00 & 4.85 & 3.65 & 3.04 & 0.37 \\
\hline $\mathrm{CaO}$ & 8.98 & 7.72 & 8.62 & 7.58 & 6.80 & 7.10 & 26.66 & 17.10 & 15.86 & 12.0 & 3.90 & 5.25 & 1.55 \\
\hline $\mathrm{Na}_{2} \mathrm{O}$ & 4.93 & 3.06 & 3.46 & 5.81 & 5.33 & 5.11 & 0.80 & 2.96 & 0.86 & 1.84 & 3.64 & 4.11 & 0.28 \\
\hline $\mathrm{K}_{2} \mathrm{O}$ & 1.31 & 1.84 & 1.31 & 1.73 & 1.50 & 1.42 & 0.10 & 0.42 & 2.36 & 1.95 & 4.38 & 1.58 & 0.21 \\
\hline $\mathrm{P}_{2} \mathrm{O}_{5}$ & 1.11 & 0.40 & 0.40 & 0.51 & 0.59 & 1.05 & 0.16 & 0.38 & 0.12 & 0.12 & 0.31 & 0.19 & 0.03 \\
\hline
\end{tabular}

1-10 - Hilmand (Afghan) block: 1-3 - trachybasalts, 11 - syenite, Lar massif, 12 - 13 - Bazman volcano, Neogene - Quaternary, author's data; 2, 7,10 - data by A. Houshmandzadeh and M.A.A. Nogol Sadat et al., 3 and 4 - (Camp, Griffis, 1982), ‘- symbol means - not determined. 
Table 7. Rare Earth Elements (REE) in the rocks studied and standards

\begin{tabular}{|c|c|c|c|c|c|c|c|c|c|}
\hline Component & 1 & 2 & 3 & 4 & 5 & 6 & 7 & 8 & 9 \\
\hline $\mathrm{La}$ & 32.4 & 32.1 & 44.8 & 18.6 & 35.2 & 34 & 63 & 78 & 31.3 \\
\hline $\operatorname{Pr}$ & 8.23 & 8.05 & 9.80 & 4.32 & - & - & - & - & - \\
\hline $\mathrm{Nd}$ & 31.4 & 32.9 & 37.8 & 17.7 & 25.0 & 43 & 70 & 63 & 21.3 \\
\hline $\mathrm{Sm}$ & 6.00 & 5.98 & 7.24 & 3.92 & 5.1 & 10 & 17 & 12 & 4.09 \\
\hline $\mathrm{Eu}$ & 2.11 & 1.83 & 1.31 & 1.23 & 1.9 & 3.0 & 4.5 & 4.0 & 1.26 \\
\hline Gd & 5.08 & 5.55 & 6.19 & 4.20 & 4.8 & 7.5 & 11 & 10 & 3.42 \\
\hline $\mathrm{Tb}$ & 0.78 & 0.71 & 0.70 & 0.54 & - & - & - & - & 0.55 \\
\hline Ho & 0.68 & 0.57 & 0.64 & 0.69 & - & - & - & - & - \\
\hline $\mathrm{Er}$ & 1.26 & 1.40 & 1.93 & 2.21 & 1.6 & 2.8 & 3.7 & 2.9 & 1.79 \\
\hline $\mathrm{Tm}$ & 0.31 & 0.26 & 0.26 & 0.32 & - & - & - & - & - \\
\hline $\mathrm{Yb}$ & 1.26 & 1.10 & 1.74 & 2.23 & 1.6 & 1.8 & 2.4 & 2.8 & 1.94 \\
\hline $\mathrm{Lu}$ & 0.34 & 0.23 & 0.25 & 0.34 & - & - & - & - & - \\
\hline
\end{tabular}

1-4 - intraplate rocks in West Baluchestan: 1-2 - trachyandesites, Neogene (r70-2 and r70-23 samples, analytics by A. Housmandzadeh and M.A.A. Nogol Sadat support); Helmand basin, 3-4 - subalkaline rocks, Lut block (r75-1 and r75-2); 1-4 - analytics by A. Housmandzadeh and M.A.A. Nogol Sadat support; 5-trachyandesite, standard, continental rift, Paleoproterozoic, Kuetsjarvi unit, Pechenga zone, Fennoscandian Shield by A. Romanko et al.; 6-8 - basalt and dolerite (intraplate standard rocks), continental rift, Jurassic, Karoo formation, Save-Limpopo rift, Zimbabwe, E. and A. Romanko; 9 - trachyandesite, Eocene, subduction-related setting, sample BH-13 from a well, Talmessi deposit, Central Iran, courtesy of H. Bagheri.

We have received fair low isotopic data $87 \mathrm{Sr} / 86 \mathrm{Sr}$ (ISr) in two samples of intraplate rocks: trachyandesite $\mathrm{R} 70-2=$ $0.7039 \div 0.2($ high $\mathrm{K} / \mathrm{Rb}=393)$ and trachybasalt $\mathrm{R} 71-4=$ $0.70489 \div 0.18(\mathrm{~K} / \mathrm{Rb}=375$, as seen from Table 4). For subduction-related calc-alkaline andesite of Bazman stratovolcano differentiated series (no doubts about this tectonics here), sample R25 was determined a fairly low value $\mathrm{ISr}=0.70456 \div 0.05, \mathrm{~K} / \mathrm{Rb}$ principally lower - ca. 250 as seen from Table 1. Isotopic data of these our intraplate rocks differing from collisional and subduction-related rocks from Anatolia, Turkey (Dilek et al, 2010; Khain, 2001; Imamverdiyev, 2008 etc.). Calc-alkaline igneous rocks of the Bazman volcano zone in the regional Sahand - Bazman belt are of differentiated basalt-dacite series. Known stratovolcanoes in this belt are: Bazman with a height $3490 \mathrm{~m}$ and Taftan $3940 \mathrm{~m}$ (old mark was $4042 \mathrm{~m}$ ). Old 0.7049 isotopic date for a 'volcanite' of an unnamed volcano in a desert was reported by Camp and Griffis in 1982 (Camp, Griffis, 1982).

Melt inclusions (as well as fluid ones (Tables 2 and 3) - by Dr E. Romanko et al., 2000) were maybe firstly investigated in this area under the leadership of Dr. Prokofiev in the region studied. Some conclusions on this study are:

Melt inclusions are not typical for the African super-plume-related intraplate igneous rocks due to tomography by known Ritsema's team (Bull et al., 2009 etc). 1. Unusual high/very high temperature, $1150-1180$ o C up to $1220 \mathrm{o} \mathrm{C}$ in melt inclusions were revealed in plagioclase of subduction-related K-dacite, sample 75-1 by V. Prokofiev et al, 2011 (Prokofiev, 2000; Romanko et al., 2012, Fig. 2 and 3, as from Table 2). This fairly deep, non-calc-alkaline rock was also affected by indirect /maybe indirect influence of a huge African super-plume, as proposed. Homogenization occurs under High $\mathrm{T}=1150-1220 \mathrm{oC}$ (as from Table 2; for comparing, for example, $\mathrm{T}$ much lower for acid volcanite of Quaternary Pektusan volcano, N. Korea, presentation of O. Andreeva et al., Moscow, 2013). A higher viscosity of a glass provides more inclusions coexistence in a sample.

2. Maximum of fluid inclusions based on $\mathrm{CH} 4, \mathrm{C} 2 \mathrm{H} 5$ etc. composition is in carbonate-rich host rocks, west of known Taftan stratovolcano as in Table 3. Also, high concentration of them are in important alkaline subalkaline $\mathrm{Lar}$ intrusive (Pg3-N1 age) with $\mathrm{Cu}-\mathrm{Au}$ mineralization. Minimum of fluid inclusions comcentration is in ophiolitic rocks ( $\mathrm{K}$ or problematic $\mathrm{K}-\mathrm{Pg} 1$ age) as seen in Tables appendix, down of this paper (Table 3).

Intraplate rocks of the second group rocks are deeper by a source versus calc-alkaline ones of the first group. This is supported by the following:

3. Geological, petrographic, and mineralogical data

4. General style of petrology and geochemistry of these rocks similar to intraplate rocks of other regions. Indicative geochemistry including ratios etc, for example, the stable higher $\mathrm{K} / \mathrm{Rb}=560-586-620$ for intraplate rocks vs 245-307-262-230 etc. for subduction-related ones etc.

We suppose, at least, a partial compensation of 
compression (with subduction-related magmatism) by an extention of intraplate magmatism. So, tectonic-magmatic pair could be postulated here. Intraplate magmatism, according to a known tomography here (Bull et al., 2009), may be associated with the tail of a powerful African superplume. Probably, there is also a partial screening of the plume by a subducting plate due to a modelling that shows that the plate does not stop the lateral movement of the superplume.

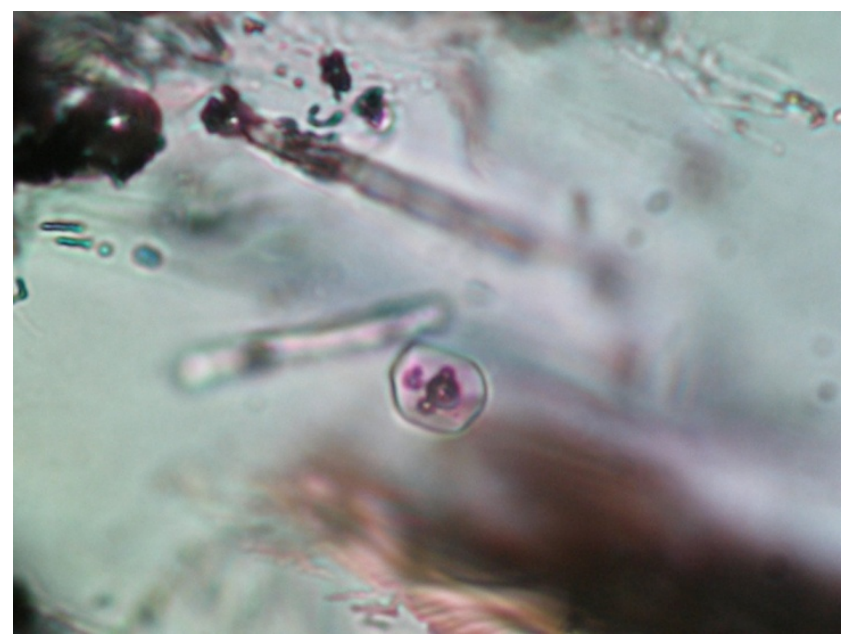

Figure 2. $\mathrm{T}=1150 \mathrm{o}$ Celcium. View of melt inclusions in acid glass from Plagioclase (Table 2)

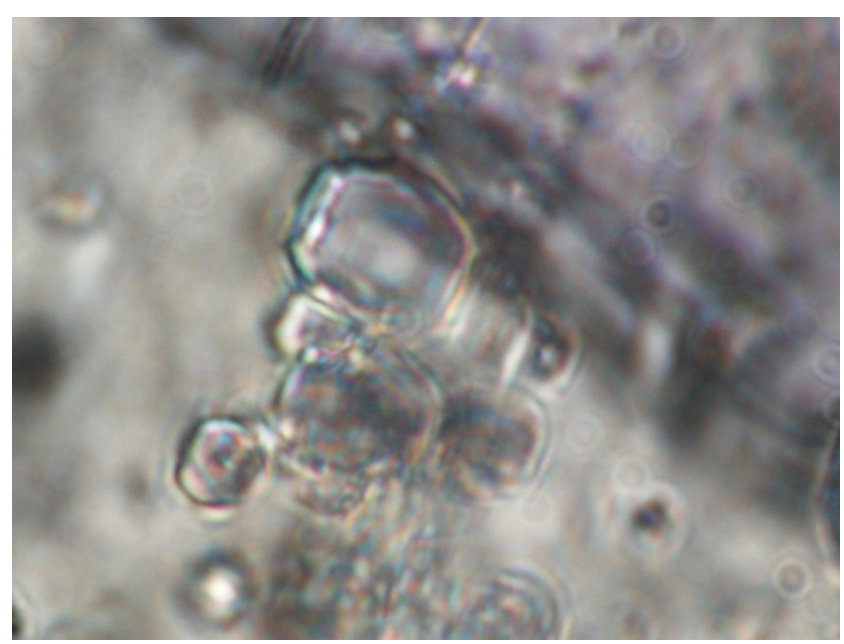

Figure 3. $\mathrm{T}=1220 \mathrm{oC}$. Homogenization of the melt inclusions.

\subsection{Metallogenic Questions}

Subduction-related intrusive, extrusive, pyroclastic and volcanogenic-sedimentary rocks of the first group and are characterized by a copper-gold $(\mathrm{Cu}-\mathrm{Au})$ metallogenic type. This corresponds to a metallogeny of all mentioned Sahand Bazman belt. Almos all mineralization associates with the very magmatic complexes in the region studied. Dr. Eugene Romanko has revealed such metallogenic types here as:
1. Multi-sulfide
(Au-Mo-Cu-Pb-Zn) subvolcanic porphyry type

2. Au-As-Hg-W-Mo-volcanic exhalation one
3. Low-sulfide gold-silver plutonic one

4. Gold-copper (Au-Cu) skarn and plutonic-hydrothermal one (E. Romanko et al., 2000) using also known data on other mineralization (Prokofiev et al., 2000; Vikentiev et al., 2004 etc.)

5. Sulfide, sulfur, alunite exhalation, surface one

6. Native-copper-sulphide volcanogenic one with zeolites

7. Silver volcanogenic sulphide (+- gold) one or sulphide $\mathrm{Ag}(\mathrm{Au})$.

Intraplate rocks are strongly specialized in REE, P (usual process), then in $\mathrm{Sr}, \mathrm{Ba}, \mathrm{U}$, Th due to nowdays materilas. So, tectonic-magmatic, and as revealed E.Romanko metallogenic zonation in the region was revealed in the region studied (at least in the Central - East Iran). Younger magmatic products are in the northeast of region due to lithosphere subduction and decreasing of African superPlume activity in the same direction.Subduction-related (1 group of rocks) dominated calk-alkaline rocks and shoshonites-latites., and, Intraplate African superPlume-related (Laverov et al., 2004; Yarmolyuk, personal communication, 2012, etc.) subalkaline - alkaline rocks including known Pleistocene carbonatites of Hanneshin, Afghanistan and, also, of one of Arabia are subordinated (2 group of rocks). Rocks of 1 and 2 groups are interpreted by us as a tectonic-magmatic pair. In this case, at least, partial compensation of subduction compression by the intraplate extension is possible. The presence of the mentioned Cenozoic intraplate carbonatite-derived depth of the melt - an argument in favor of the African superplume influence on the magma plume of a large region, which is in agreement with effective tomography of the well-known J. Ritsema's team (Bull et al., 2009). Also, There are materials about of oil/HC productivity decreasing in the direction mentioned as stressed known Prof. V. Khain from the Geological Institute, RAS, Moscow and Lomonosov Moscow State University with co-authors in the Explanatory map of Caspian Sea region scale 2: 2500 000, 2003, from the extremely rich Persian Gulf to South - Middle - North Caspian Sea zones, which is in agreement with the increasing distance from the African superplume, within the known hydrocarbon belt (Khain, 2001 etc.; Romanko et al., 2012; etc.). More specifically, this HC global belt is the Persian Gulf - Russian Arctic coast one due to old Russian maps, ex, USSR oil structures map scale 1:2500 000 etc.. HC productivity decreasing is in agreement with the increasing distance from the African superplume as seen by a tomography mentioned above. Also, salt domes are oriented due to northeast direction with respect to African superplume in the east Persian Gulf. More HC data needed, surely.

\section{Discussion}

Our data are in general agreement with African superplume - tectoncs - magmatism - metallogeny +- 
hydrocarbons (HC) relation. However more data needed on $\mathrm{HC}$ distribution and their peculiarities meaning known Russian etc. works on deep oil, ex., by Institute of oil and gas problems of Academy of Sciences, Moscow, A. Dmitrievsky et al., P. Kropotkin (Geological Institute, RAS, Moscow), A. Timurziev et al., (CGE, Moscow) G. Gogonenkov et al. etc. (CGE, Moscow) and etc. Special discussion is out of the ditrect paper task and needs much more space.

\section{Conclusion}

1. Northeast tectonic-magmatic zonation and partly metallogenic one (last one by E. Romanko) in the region studied was revealed. It caused maybe directly by known Arabian plate subduction under the Central Iran. But African superPlume controls magmatism, hot regional tectonic regime, and maybe even all geology including Jurassic Karoo flood basalts event, then Paleogene magmatism in the East Africa and Paleogene subduction, 11-9 Ma opening of Red Sea etc., maybe delamination of a slab in East Mediterranean (Khain, 2001; Imamvediyev, 2007, Romanko et al., 2012 etc.) etc.

2. Two different types of Cenozoic magmatic rocks (antipodes) were revealed. Dominated Oligocene-Recent calc-alkaline and subalkaline alkaline Neogene-Quaternary ones. First, the calc-alkaline subduction geodynamic setting are responsible, and second - intraplate. Energetically favorable tectonic-magmatic pair with these types of rocks exists. Igneous rocks of the second group are generated deeper in comparison with the first group rocks, although sudden high/very high temperature on melt inclusions in High-K subduction-related rocks were firstly received by known specialist V. Prokofiev (Prokofiev, 2000; Prokofiev et al., 2007, Romanko et al., 2012\}. Calc-alkaline rocks are characterized by an economic copper-gold+-silver $(\mathrm{Cu}-\mathrm{Au}+-\mathrm{Ag})$ regional subduction-related mineralization with a subordinate different mineralization (Au-Ag low-sulphide, Ag-sulfide maybe with $\mathrm{Au}$ etc.). Intraplate rocks bear REE, $\mathrm{P}$, also $\mathrm{Sr}, \mathrm{Ba}, \mathrm{Th}$, and $\mathrm{U} . .$. mineralization due to our data.

3. Deep processes - versus upper crustal ones - mainly control magmatism, tectonics and then metallogeny in the region studied. "Hot" tectonic regional regime is controlled mainly by African superPlume activity. $\mathrm{Cu}-\mathrm{Au}$ etc. regional mineralization in the region studied and in all country is in a good agreement with a regional Paleogene subduction and geology.

We are extremely grateful to outstanding regional trio Drs. E. Romanko广, A. Houshmandzadeh, and M. A. A. Nogol Sadat for their leadership in a field and special support, in addition - V.V. Slavinsky (consulting and ctiticism), A. Savichev and S. Stepanov†', M. Hosseini (Qom University\},
M. Heidari, S.M. Tabatabeimanesh S.R., B. Zolotarev and V. Lyakhovich†, V.Yarmolyuk, V. Trifonov, Yu. and M. Leonov, G. Karpova, M. Buyakayte, V. Petrova, I. Gablina, Yu. Malinovsky, S. Palandzhyan and G. Nekrasov, A. Shchipansky, G. Makarychev†, V. Rusinov†, V. Kovalenko†, I. Kravchenko†, A. Girnis, A. Pertsev, A. Mokhov, V. Volkov, N. Tarasov, S. Bubnov, G. Moralev; also to A. Meskhi from Kazan, Russia, and more other different specialist for long discussions, different advices, analytical support etc.

This work was supported by the RF Basic Research, project 03-05-64805.

\section{REFERENCES}

[1] Abdullah S., Chmyrev V., Dronov V., Ed., 1980. Geology and Mineral Resources of Afghanistan. Moscow: Nedra. Book 1, p. 535, Book 2, p. 336, In Russian.

[2] Alinaghi A., Koulakov I., Thybo H., 2007. Seismic tomographic imaging of $\mathrm{P}$ - and $\mathrm{S}$-waves velocity perturbations in the upper mantle beneath Iran. Geophysical J. International, 169, pp. 1089-1102.

[3] Artemiev M., 1971. Some features of the deep structure of the Mediterranean type basins according to isostatic gravity anomalies. Bull. Moscow Society of Naturalists, Dept. Geol., No 4, pp. 30-41, In Russian.

[4] Bogatikov O.A, Kovalenko V.I., Yarmolyuk V.V., Bubnov S.N., 1987. Series of igneous rocks: problems and solutions. Reports of the Academy of Sciences of the USSR, Series Geol, No 3, pp 3-12, In Russian.

[5] Bull A.L., McNamara A.K., Ritsema J., 2009. Plume clusters and thermochemical piles. Earth Planet. Sci. Lett. Volume 278, pp. 152-162.

[6] Dilek Y., Imamverdiyev N.A., Altun-kaynak Şafak, 2010. Geochemistry and tectonics of Cenozoic volcanism in the Lesser Caucasus (Azerbaijan) and the Peri-Arabian region: Collision-induced mantle dynamics and its magmatic fingerprint. International Geology Review, volume 52, issue 4-6, pp.536-578.

[7] Hushmand-Zadeh A., Nabavi M.H., 1986. Metamorphic Map of Iran Scale 1: 2,500,000. Tehran: Geol. Survey. Iran.

[8] Imamverdiyev N.A. 2000. Geochemistry of Late Cenozoic volcanic complexes Lesser Caucasus Baku. Nafta-Press. 2000. 192 p.

[9] Imamverdiyev N.A. 2008. Delamination of subducted lithospheric slab as the cause of Late Cenozoic volcanism in the Lesser Caucasus. News of Baku University. Natural sciences Series. No 3, pp.123-138.

[10] Khain V., 2001. Tectonics of Continents and Oceans (year 2000). Moscow: Scientific World, 2001. 606 p, In Russian.

[11] Koronovsky N.V., Demina L.I., 1999. Collisional stage of the Caucasian sector Alpine fold belt: geodynamics and magmatism. Geotectonics. No 2, pp. 17-35.

[12] Koronovsky N.V, Lomize M.G., 2006. Tectonic accretion 
and collision as the steps of forming inter-continental fold belts. Areas of active tectonics in modern and ancient history of the Earth. Materials. 39 Tectonic meeting. Vol. 1, Moscow: GEOS. pp. 353-357.

[13] Laverov N., Kovalenko V., Yarmolyuk V. et al., 2006. The latest volcanic activity in Northern Eurasia: Zoning and environment of formation. Russian Academy of Sciences (RAS) Reports. Vol. 410. No 4, pp. 498-502, In Russian.

[14] Luchitsky I.V., 1985. Palaeovolcanology. Moscow: Science (Nauka), 235 p., In Russian.

[15] Milanovsky E.E., Koronovsky N.V., 1973. Orogenic volcanism and tectonics of the Alpine belt of Eurasia. Moscow: Nedra, $280 \mathrm{p}$.

[16] Prokofiev V.Yu., 2000. Geochemistry of ore-forming fluids of hydrothermal gold deposits of different genetic types according to the study of fluid inclusions. Moscow. Science (Nauka), Novosibirsk, $192 \mathrm{p}$.

[17] Prokofiev V.Yu., Bortnikov N.S., Zorina L.D., Kulikova Z. I., Matel N. L., 2000. The Darasun intrusive-related gold-base metal deposit, Eastern Transbaikalia, Russia: Petrochemical, melt and fluid inclusion, REE and stable isotope $(\mathrm{O}, \mathrm{C}$, and $\mathrm{S})$ studies. Applied Mineralogy. Rammlmair et al., Eds. Balkema, Rottertdam, Brookfield, 399-402 pp.

[18] Romanko E., Kokorin Y.., Krivyakin B. et al., 1984. Outline of metallogeny of Anarak Area (Central Iran). Ministry of mines and metals. Geological Survey of Iran. Rep. 21, Tehran. Techno export, $136 \mathrm{p}$.

[19] Romanko E., Voinkov D., Houshmandzadeh A. et al., 2000.
Characteristic features of ore mineralization in the Sistan-Baluchestan Province, SE Iran: evidence from fluid inclusions data. International conference on geology of Mediterranean belt. Absracts. Beograd.

[20] Romanko E., Romanko A., Meskhi A., 1998. On a Geology and Geochemistry of Mesozoic - Cenozoic igneous rocks in NE Algeria. Reports of Academy of Sciences (RAS). 1998. Vol.362, No 2, pp. 236-238, in Russian.

[21] Romanko A., 2005. New data on Cenozoic subalkaline intraplate rocks the East Iran. Reports of the Academy of Sciences (RAS). Vol. 404, No 4, pp. 510-513.

[22] Romanko A., Imamverdiyev N. A., Prokofiev V., Tabatabaeimanesh S. M., Vikentiev I., Savichev A., Stepanov S., 2012. On Cretaceous - Quaternary magmatic tectonic - metallogenic peculiarities in Northeast Iran and South Tajikistan: new data melt inclusions, constraints, and some problems. European Seismological Commission Assembly. ESC. Book of abstracts. M. Polygraph, pp. 154-155.

[23] Sandwall E., Turkell N., Zor E. et al., 2003. Shear wave splitting a young continent collision. Geophys. Res. Lett., 30. No 24 b, pp.185.-194.

[24] Vikentyev I.V., Yudovskaya M.A., Mokhov A.V. et al. 2004. Gold and PGE in massive sulphide ores of the Uzelginsk deposit, Southern Urals, Russia. Canadian Mineralogist. Vol. 42, No 5, pp.651-665.

[25] Yarmolyuk V.V., Kovalenko V.I., Bogatikov O.A., 1990. South Baikal "hot spot" mantle and its role in the formation of the Baikal Rift region. Reports of Russian Academy of Sciences (RAS). Vol. 312, No 1, pp.187-191, In Russian. 